\title{
Etiología de las infecciones agudas del tracto respiratorio bajo (IRAB) en lactantes hospitalizados: estudios virológicos
}

\author{
Dra. Ana María Escobar C. ${ }^{1}$; Dx. Fernando Martínez R. ${ }^{1}$; Dra. Eliana Ceruti D. ${ }^{1}$; \\ Dr. Armando Díaz C. ${ }^{1}$ : QF Manuela Vicente $\mathrm{S}^{2}$; TM Pedro Farías T. ${ }^{1}$; \\ TM Graciela Torres ${ }^{2}$; Dra. Patticia Vernal S. ${ }^{1}$

\begin{abstract}
Virological studies in infants with low respiratory tract infections and in healthy controls
\end{abstract}

\begin{abstract}
Virological studies were done in a group of 1 I 2 infants undex one year of age hospitalized with acute lower respiratory infections and in $4 \mathrm{l}$ healthy controls of the same age. Samples of nasopharyngeal aspirates were taken in both groups. Smears for immunofluotescence of respiratory syncytial virus (RSV), parainfluenza type 3 virus, adenovirus and direct viral isolation technics were performed. Matched samples for serology were also done in 38 cases. Virological studies were positive in 22.3 percent of patients: in 82.7 percent of them RSV was demostrated while in 16.0 percent there were viral associations. The virological studies in the control group were positive in 36.6 percent of cases for RSV and cytomegalovirus. This results confirms the role of RSV in the etiology of bronchoptheumonia in infants under one year of age.

(Key words: respiratory tract infections, pneumonia viral, respiratory syncytial virus, para influenza type 3 virus, adenoviruses).
\end{abstract}

Las infecciones respiratorias agudas constituyen una de las principales causas de consulta en los servicios de salud y ciertamente las infecciones respiratorias agudas del tracto respiratorio bajo (IRAB), bronconeumonia, una causa importante de muerte en niños menores de 1 año ${ }^{1}$. Existen pocos datos referentes a su etiologia en nuestros países; estudios previos en nuestro departamento ${ }^{2}$ y en otros hospitales de San. tiago ${ }^{3-5}$ han demostrado que los virus juegan un rol relevante en la IRAB en lactantes menores, lo que nos acerca a los países desarrollados ${ }^{6-10,11}$. Sin embargo, sigue persistiendo un número no

1. Unidad de Enfermedades Respiratorias. Departamento de Pediatria, Escuela de Madicina, Division Norte, Universidad de Chile.

2. Sección Virología Clínica, Unidad Respiratoria Instituto de Salud Pública.

Trabajo de incorporación de la Dra. Ana María Escobar Ceruti a la Sociedad Chilena de Pediatría.

Trabajo financiado por Grant to 0135 Fondecyt $1986,1987,1988$.

Trabajo financiado por Grant No 2343-8612 Departamento Investigación y Bibliotecas Lniversidad de Chile, $1986,1987$. despreciable de bronconeumonías bacterianas, difíciles de pesquisar por los obstáculos inheren. tes a la obtención de muestras bacteriológicamente representativas.

Actualmente existen técnicas rápidas para investigación virológica ${ }^{12-16}$ y bacteriológica, entre estas últimas aghutinaciones por látex $^{17-21}$, contrainmunoelectroforesis ${ }^{17,19}, \mathrm{co}-$ aglutinación ${ }^{19,20}$ y microinmunofluorescencia indirecta para chlamidia trachomatis ${ }^{22}$, que permitirian identificaciones etiológicas más certeras y oportunas.

Con el fin de dilucidar las dudas antes mencio. nadas se propuso una investigación clínica, bacteriológica y virológica para determinar los agentes etiológicos más frecuentes de las IRAB del lactante, con objeto de establecer la frecuencia relativa de los virus y bacterias, incluyendo la chlamidia trachomatis; promover el desarrollo y estandarización de pruebas de diagnóstico etiológico no invasoras; caracterizar los síntomas asociados con gérmenes patógenos específicos; conocer y evaluar a largo plazo las secuelas de las IRAB producidas por virus; definir mejor las co- 
rrelaciones clínico-epidemiologicas y tratamientos más racionales y menos empíricos de las bronconeumonías del lactante.

En este trabajo se presentan en forma preliminar los resultados virológicos obtenidos durante 1987. En una siguiente publicación se darán los resultados del estudio bacteriológico.

\section{MATERIAL Y METODO}

El trąajo contemplá el estudio de 112 pacientes menores de 1 año con bronconeumonja comprobada clinica y radiológicamente y de 41 controles sanos de igual edad, en el período comprendido entre mayo $y$ octubre 1987

En todos los lactantes se tomaron muestras de aspirado nasofaríngeo, mediante técnica umajersal, con un catéter conectado a un equipo de succión traqueal. Con material sc efectuó de inmediato frotis para inmunofluorescencia de virus respiratorio sincicial (VRS), adenovirus (Ad) y parainfluenza tipo $3\left(\mathbf{P}_{3}\right)$. Con e] mismo equipo se tomaron muestras para aislamiento viral, las que fueron inoculadas en cultivos celulares sensibles a virus respiratorios: celulas Hep-2 y células diploides de puhnón humano fetal.

Simultáneamente, en 38 casos, se tomaron muestras, en periodo agudo y posteriormente en etapa de convaleciente para serología viral.

Al mismo tiempo se obtuvieton muestras para investigación de IgM específica antichlamidia y sc recolectó orina estéril, guardándola centrifugada a $-70^{\circ} \mathrm{C}$, para ulteriores determinaciones de antígenos bacterianos y citomegalovirus.

Todos los datos clínicos, epidemiológicos y resultados de laboratorio se registraron día a día durante la hospitalización y en una visita al paciente 15 dias después del alta.

\section{RESULTADOS}

Se consideraron positivos los hallazgos virales obtenidos por inmunofluorescencia y o aislamiento y serología.

En la tabla 1 se muestran los resultados obtenidos en los 112 pacientes estudiados. Se observa que en 81 pacientes $(72,34)$ la investigación virológica fue positiva.

En la tabla 2 se observan en forma separada los agentes virales encontrados en los 81 positivos. En 13 de ellos $(16,0 \%)$ se demostró la presencia de virus asociados. Destaca la alta frecuencia del VRS en $82,7 \%$ de los niños con virologia positiva y de citomegalovirus en 14,8\% de ellos.

En la tabla 3 se muestran las asociaciones virales encontradas: destaca el hecho que en 12 de los 13 casos confirmados se encontró evidencias de VRS.
Tabla 1

lnvestigación de vìus en 112 lactantes menores con bronconeumonía

\begin{tabular}{lcc}
\hline & No pacientes & Porcentaje \\
\hline Positivo & 81 & 72,3 \\
Negativo & 31 & 27,7 \\
TOTAL & 112 & 100,0 \\
\hline
\end{tabular}

Tabla 2

Distribución de agentes virales en 81 lactantes menores con bronconeumonía

\begin{tabular}{lcr}
\hline Virus & No pacientes & Porcentaje \\
\hline VRS & 67 & 82,7 \\
Adenovirus & 8 & 9,9 \\
Parainfluenza 3 & 1 & 1,2 \\
Influenza A & 1 & 1,2 \\
Citomegalovirus & 12 & 14,8 \\
Enterovirus & 6 & 7,4 \\
\hline
\end{tabular}

Se detectaron 13 infecciones virales mix tas $(16,0 \%)$.

Tabla 3

Distribucjón de agentes virales en 13 lactantes menoses con bronconeumonia e infecciones mixtas

\begin{tabular}{lc}
\hline Virus & No pacientes \\
\hline VRS + adenovirus & 3 \\
VRS + citomegalovirus & 8 \\
VRS + influenza A & 1 \\
Adenovirus + enterovirus & 1 \\
TOTAL & 13 \\
\hline
\end{tabular}

En la tabla 4 se observan los resultados obtenidos en los 41 controles. En $15(36,6 \%)$ la virología fue positiva. Finalmente, en la tabla 5 se observa la distribución de los agentes virales encontrados en los ninos controles, siendo los más frecuentes VRS y citomegalovirus. 
Tabla 4

Inyestigación de virus en 41 controles sanos

\begin{tabular}{lcc}
\hline & No controles & Porcentaje \\
\hline Positivo & 15 & 36,6 \\
Negativo & 26 & 63,4 \\
TOTAL & 41 & 100,0 \\
\hline
\end{tabular}

Tabla 5

Distribución de agentes virales en 15 lactantes controles presuntamente sanos

\begin{tabular}{lc}
\hline Virus & No controles \\
\hline VRS & 7 \\
Adenovirus & 1 \\
Parainfluenza 3 & 1 \\
Citomegalovirus & 8 \\
Fnterovirus & 1 \\
\hline
\end{tabular}

Se detectaron 3 controles con virus asociados.

\section{COMENTARIO}

Es ampliamente conocido desde los primeros trabajos de la Dra. Hall ${ }^{23}$ que el primer contacto con el virus respiratorio sincicial generalmente es sintomático, variando entre una infección respiratoria leve, a una baja grave o bronconeumonía.

En la mayoría de los pacientes estudiados en este trabajo, todos lactantes menores con bron. coneumonía, la identificación viral fue positiva, encontrándose preferentemente VRS, ya sea como agente único o asociado a otros virus: este hallazgo concuerda con observaciones en países desarrollados y en el nuestro, en grupos similares de niños ${ }^{2-9}$.

La frecuencia de asociación del VRS con otros vinus y también con bacterias ha sido frecuentemente descrita y se hace más relevante al utilizar simultáneamente diversas técnicas de laboratorio. La capacidad diagnóstica ha aumentado notablemente con la inmunofluorescen$\operatorname{cia}^{12-1 s}$, técnica que como se demuestra en este trabajo optimiza la detección del VRS ya que tiene un mejor rendimiento que el aislamiento y la serología $a^{2,12}$.
Al comparar los resultados obtenidos para los otros virus con trabajos anteriores, llama la atención la escasa participación de los adeno. virus $y$ parainfluenzas ${ }^{3-5}$. Este hecho podría deberse a que en esta muestra se aplico una selección más estricta de los pacientes (todos menores de 1 año, con bronconeumonía comprobada y con menos de 5 dias de evolución) lo que disminuye ciertamente las posibilidades de infección intrahospitalaria. También podría estar influyendo la variación estacional, ya que el VRS es epidémico en los meses de invierno en Santiago, periodo en que se estudió la mayoría de los pacientes ${ }^{3}$.

Diversos autores han demostrado que el aislamiento del VRS en niños sanos es excepcional, por lo que su hallazgo implicaria un rol patogénico $^{7,23-27}$. Sin embargo, llama la atención en este trabajo que en el grupo control estudiado encontró VRS en 7 niños $(17,0 \%)$. Esta cifra, demasiado alta, la interpretamos como una falla en la selección, ya que estos lactantes podrían haber estado sufriendo infecciones respiratorias agudas altas clínicamente inadvertidas. Por la fácil y amplia diseminación de este virus en la población menor de un afio, es muy dificil obtener controles sanos. En todo caso, la participación del VRS en los pacientes fue 3,5 veces mayor a la observada en lactantes sanos.

Otro hecho importante es la presencia citomegalovirus, tanto en los pacientes $(10,7 \%)$ como en los controles sanos $(19,5 \%)$, lo que nos permite pensar que más bien se trate de niños portadores de este virus. La explicación del rol jugado por el citomegaloyirus en los 4 pacientes en los que detectó como virus único sólo la podremos interpretar cuando se complete e] análisis total del presente estudio.

En resumen, por ser este trabajo una presentación preliminar sus conclusiones finales sólo podrán ser confirmadas cuando se reatice el análisis completo, viral, bacteriano, clínico y epidemiológico. Sin embargo, no puede dejarse sin destacar la importancia del VRS, ya sea como agente único o asociado a otros virus, en un grupo importante de lactantes menores con bronconeumonía. Su hallazgo en los primeros días de hospitalización permitiría asegurarle un rol patogénico y evitar o suspender en muchos de ellos terapias antibióticas no efectivas. También cabe destacar que el uso rutinario de métodos rápidos de investigación virológica dan alertas 
en la prevención de la diseminación del VRS dentro del hospital, lo que es particularmente importante en grupos de alto riesgo: prematuros, lactantes menores de 6 meses, pacientes con displasia broncopulmonar, cardiopatías congéni. tas y daño neurológico.

Finalmente, la detección precoz del VRS permitirá en un futuro cercano en nuestro país tratar los pacientes de alto riesgo con Ribaviri$n^{28}$; mejorando evidentemente su pronóstico.

\section{RESUMEN}

Se analizan los estudios virológicos practicados en un grupo de 112 lactantes menores de 1 año hospitalizados por infección respiratoria aguda del tracto respiratorio bajo y en un grupo de 41 controles de igual edad. En todos se tomaron muestras de aspirado nesofaríngeo realizándose frotis para inmunofluorescencia (VRS, $P_{3}$, Ad) y aislamiento viral y en 38 casos muestras pareadas para serologia. En $72,3 \%$ de los pacientes la investigación virológica fue positiva, demostrándose en $82,7 \%$ de ellos VRS y en $16,0 \%$ virus asociados. Se destaca la alta frecuencia del VRS. En el grupo control el estudio virológico fue positivo en $36,6 \%$ de los casos, detectándose citomegalovirus y VRS fundamentalmente. Estos resultados confüman la importancia del VRS en la bronconeumonia del lactante menor de 1 año.

\section{AGRADECIMIENTOS}

Nuestros agradecimientos al Dr. José Maruel Borgoño, Sefe de la Oficina de Asuntos Internacionales, Ministerio de Salud, por su valioso aporte en equipos que facilitó la realización de este trabajo.

\section{REFERENCIAS BIBLIOGRAFICAS}

1. Toro $\mathrm{S}_{\text {.: }}$ Mortalidad por infecciones tespiratorias agudas en Chile. Pediatría (Stgo.) 1986; 29: 6567.

2. Méndez B., Goldemberg E., Vicente M. et at. Díagnóstioo rápido de Virus Respiratorio Sincicial por técnica de inmunofluorescencia en infecciones respiratorias agudas bajas. Pediatría (Stgo.) 1987; $30: 235-240$.

3. Vicente M., Carrosco L., Burdach R. y Wu E.: Diagnóstion virológioo de virus respiratorios en niños. 1a. Conferencia Internacional sobre el impacto de las enfermedades virales en el desarrollo de los paises latinoamericanos y de la región del Caribe. Vol. III: $581-591,1982$. Río de Janeiro, Brasil.

4. Burdach $R$, Vicente $M$., Carrasco L. et al., Etiología vìal en afecciones broncopulmonares agudas y recidivantes de la infancia". Rev Chil Infectol. 1987; 4: 104-109.

S. Vicente $M$, Wh E, Carrasco L. et al.: Detección viral en infecciones respiratorias agudas bajas en niños. Estudio sesológico. Enf. Resp. y Cir. Tórax 1988: $4: 10-14$.

6. Eriksson $M_{\text {. }}$, Forsgren M., Sioberg $S$. et al.: Respiratory syncytial viral infection in infants with congenital heart dikease. Acta Pediatr Scand 1983; 72: 47.51

7. Kim H.W., Arrabio J., Bront C.D. et al, Epidemiology of respiratory syncytial virus infection in Washington D.C.: Importance of the virus in different respiratory tract disease syndromes and tempored distribution of infection. Am J Epidemiol 1973;98: 216-225.

8. Anónimo: Acute respiratory infections $\mathrm{RD} / 21 / 3$ Pan Amcrican Health Organization. WHO, 1983 Washington, $\mathrm{DC}$.

9. Downthom M.A.P.S., Gantner P., McQuillin J., Ferris $J$.: Role of respiratory viruses in childhood mortality. BI Med J 1975; 1: 235-239.

10. Boyer $K$. and Cherry $J$. : Non Bacterial Pneumonia. In Fetgin, $K$. and Cherry, J. Textbook of Pediatric Infectious Diseases. Philadephia W.B. Saunders Co, $1981 ; \mathrm{pp}$. 186-196.

11. Long $S$.: Treatment of acute Pneumonia in infants and children. Pediatt Clin North Am 1983; 30: 297-321.

12. Gardner P.S., McQuillin J.: Application of inmunofluorescent antibody technique in the rapid diagnosis of respiratory syncytial virus infections. Br Mcd J 1968; 3: 340-343.

13. Cradock-Watson J.E., McQuillin J., Gardner P.S.: Rapid diagnosis of respiratory syncytial virus infection in children by the immunofluorescent technique. J Clin Path 1970; $24: 308-312$.

14. Friedman A., Shello $N$., Arens $M$. et al.: Vahe of rapid diagnosis of respiratory syncytial virus infection on management of small infants. Clin Podiatr $1986 ; 25: 404-406$.

15. Kaul. A., Scott R., Gollagher $M$, et al.: Respiratory syncytial virus infection. Rapid diagnosis in children by use of indirect immunofluorescence. Am J Dis Child 1978; 132: 1088-1090.

16. Mintz L., Ballard R., Snidcrman $S$. et al.: Nosocomial respiratory syncytial virus infection in an intensive care nursery: Rapid diagnosis by direct immunofluorescence. Pediatrics $1979 ; 64 ; 149-153$.

17. Ward J.J., Siber G.R. et al.: Rapid diagnosis Haemophilus Influenzac type $\mathbf{b}$ infection by latex particle agglutination and counterimmunoelectrophoresis. J Pediatr 1978;93: 37-42.

18. Daum R.S., Siber G.R. et al:: Evaluation of commercial latcx particle agglutination test for rapid diagnosis of Haemophilus lnfluenzae type $b$ infection. Pediatrics $1982 ; 69: 466-471$.

19. Thirumoorthi M.C., Dajani A.S.: Comparison of staphylococcal coagglutination latex agglutination and counterimmunoelectrophoresis of bacterial antigen detection. J Clin Microbiol 1979; 9: 28-32.

20. Ramsey B.W., Marctuse E.K. et al.: Use of bacterial antigen dotection in the diagnosis of pediatric 
lower respiratory tract infection. Pediatrics 1986; $78: 1-9$.

21. Rubin L.G. and Carmody L.: Pneumococeal and Haemophilus Influenzae type b antigen detection in children at risk for occult bacteremia. Pediatrics $1987 ; 80: 92-96$.

22. Schacter J., Grossman $M$. et al: Serology of Chlamidia Trachomatis in Infants. J Infect Dis $1982 ; 146$; $530-535$

23. Hall C.: Respiratory Syncytial virus. In Feigin, $K$ and Cherry, J. Textbook of Pediatric Infectious Diseases. Philadelphia W.B. Saunders Co. 1981; pp, 1247-1267.

24. Nichol $\boldsymbol{K}$. and Cherry, J.: Bacterial viral interredation in respiratory infections of children. New Engl J Med 1967; 277; 667-672.
25. Poisley J., Later B., Mclntosh K.et d.: Pathogens associated with acute lower respiratory tract infection in young children. Ped Infect Dis 1984; 3: 14-19.

26. Chanock. R.M. RSV I Virus recovery and other observations during 1960 outbreak of Bronchiolitis, Pneumonia and Minor Respiratory diseases in childien. J A M A 1961; 176: 647-653.

27. Parrot R., Vargoska A., Kim. H. et al.: RSV It. Serologic Studies over a 34 month period of children with Bronchiolitis, Pneumonia and Minot Respiratory Diseases. J A M A 1961; 176: 653-657.

28. Committee on Infectious Diseases, American Academy of Pediatrics. Ribavitin Therapy or Respiratory Syncytial virus. Pediatrics 1987; $79: 475-478$ 